\title{
PRIVATE CONFESSION OF SIN IN THE THEOLOGY OF DIETRICH BONHOEFFER ${ }^{1}$
}

\author{
Nicola J. Wilkes \\ (nicola.wilkes@cantab.net)
}

In the thesis I argue that private confession of sin plays a significant role in Bonhoeffer's theology from his earliest writings onwards and that it is the vehicle through which he envisages the reinvigoration of the church. On Bonhoeffer's account, private confession of sin is a moment of concrete encounter with the present Christ in which the one who confesses comes out of self and into Christ and thereby into the church-community; namely, into Christ existing as church-community. In so doing the confessant displaces self as the pseudo-creator, and stands before Christ in order both to speak out truth and to hear truth; that is, she comes out of self in order to be addressed by Christ. Through this action the confessant embraces reality, receives Stellvertretung (vicarious representative action), moves from death to life, from isolation to community, and from disunity to union with Christ and his Church. Confession is the actualisation by the Holy Spirit of the already accomplished ontological reality of the reconciliation of humanity with God wrought by Jesus Christ through his incarnation, crucifixion and resurrection. The Stellvertreter, the one who hears the confession, stands before the one confessing both in the place of the church community - that is, in place of Christ — and as a fellow sinner, forgives the sin in the power of the Spirit and 'takes the sin from the other's conscience and bears it ... by... laying it on Christ' in the name of the triune God. In sum, for Bonhoeffer, private confession effects a reconstitution of personhood through the revelatory word heard in encounter with Christ.

Confession is intrinsic to Bonhoeffer's ecclesiology, theological anthropology, soteriology, hamartiology, Christology, epistemology, theology of discipleship and healing, confession (Bekenntnis) of faith,

1 Nicola J. Wilkes, 'Private Confession of Sin in the Theology of Dietrich Bonhoeffer' (Ph.D. dissertation, University of Cambridge, 2015); supervisor: Revd Dr Stephen Plant, Dean of Trinity Hall. 
ethical and sacramental theology, theological concept of Stellvertretung, interpretive hermeneutic, and philosophical critique. It is his response to the theological problem of sin, and the philosophical issue of how human beings know truth. Although his first published reference to confession, in a footnote in Sanctorum Communio, falls under the title of pastoral care, even here Bonhoeffer affords it a richer significance than one confined to pastoral issues. From the time of his visit to Rome at the age of seventeen, the notion of private confession was embedded in the framework of Bonhoeffer's thought such that it became a controlling idea decisively shaping other theological and philosophical concepts.

Bonhoeffer's theological application of confession was multifaceted and although he once described it as a 'miracle that defies explanation', he made repeated attempts to convey it, and placed great emphasis on the practice such that he put the concept to work in multiple dimensions of his theology. So, when considering his dominant theological concept of Stellvertretung, Bonhoeffer's thought turns to private confession, leading to the dual depiction of '[c]onfession of sin ... founded on the reality of the vicarious representative action of Christ', and confession of sin as the epitome of Stellvertretung. When Bonhoeffer considers the church he is driven to conclude that there is no church without private confession. In his thinking about theological ethics, he is moved to claim that without private confession of sin there can be no concrete ethics. When the theme of reconciliation comes to the forefront in his later theology, Bonhoeffer places confession at the foundation stating that it is through 'personal confession [that] we are allowed in a special way to become sure of our liberation from sin and reconciliation from God'.

At times, confession comes to the fore as a prominent theme in its own right in his work, for example in the texts of the Finkenwalde period. Yet always, confession implicitly exercises persistent and formative influence until Bonhoeffer suddenly draws attention to it with dramatic flourish. Private confession is a topic to which he constantly turned in his writings as both a pivotal point for theological discussion and also as an opportunity to appeal for the reinvigoration of the practice. In sum, Bonhoeffer's work is infused with the concept of private confession: it is foundational to his entire theological output. However, the depth and breadth of the theological significance of 
confession in Bonhoeffer's thought has not yet been mined. The thesis undertakes to address this lacuna.

The aim of the work is threefold. First, to illustrate the pervasive imprint of confession in Bonhoeffer's theology across the span of genres and doctrines in which he expressed his thought. Second, to do so with a focused - though not singular - emphasis on his earliest output, both to correct the neglect in this regard and to highlight confession's intrinsic function in these pre-Finkenwalde works. Third, to explore how and why the conceptual framework of private confession is constructed. Through the medium of a predominantly diachronic and interpretive exegetical study the thesis considers the role Bonhoeffer's theology of confession plays in his thought.

After an opening definition of Bonhoeffer's conception of confession, chapters 1-3 contextualise the theological, philosophical, political, social, and educational stimuli for Bonhoeffer's construal of the concept. Chapter one explores the twin theological and philosophical issues that Bonhoeffer's theology of confession addresses - namely, the problems of sin and of idealism. Chapter two continues the contextualisation by setting Bonhoeffer within the political and social circumstances in which he lived, worked, and developed his theological outlook. This includes an examination of that part of Bonhoeffer's biography most pertinent to his theology of private confession - his visit to Rome in 1924 - and indicates the extent to which this event shaped his subsequent theology. Chapter three explores the educational impetus by turning to the theological figure upon whom Bonhoeffer focused much of his study, and from whom he largely drew his theology of confession, namely Martin Luther (and briefly considers Löhe, himself reliant on Luther). In so doing, the chapter will clarify those points that Bonhoeffer took from Luther to furnish his confession concept and the manner in which his construal differs.

Chapter four investigates the core of Bonhoeffer's confession theology through a detailed exposition of the theological concept Stellvertretung found in his seminal work, Sanctorum Communio. This examination involves an exploration of its meaning, the manner in which it forms the foundation of Bonhoeffer's conception of confession, and a reading of Bonhoeffer's depiction of confession in this work as representing the epitome of Stellvertretung. Chapters 5-7 continue the examination of Bonhoeffer's early works - chapters five 
and six form a two-part discussion of the philosophical concepts that Bonhoeffer employed and critiqued in relation to confession, and chapter seven looks to the biblical concept underpinning his theology. In each of these chapters there is an interplay between highlighting the role that confession plays in Bonhoeffer's early writings, and gleaning the theological, philosophical, and biblical concepts which Bonhoeffer employs to consolidate his theology of confession, with the greater weight on the former.

Chapter eight then turns to the documents from the later Finkenwalde period, texts which are purposefully left until this point to allow the role of confession in prior works to come to the forefront before looking to Finkenwalde. Maintaining the sequential priority of Bonhoeffer's works, the chapter first discusses the function of confession in Discipleship, then Life Together, followed by an examination of lectures from that time span. In the doctrines that Bonhoeffer discusses, confession is again seen to be the key component.

Finally, chapter nine traces the multivalence of confession in Bonhoeffer's literary output. That is, having discussed key texts in detail, it gives a necessarily broad survey in order to consider the multiple genres of Bonhoeffer's writings - from both before and after Finkenwalde - to demonstrate that Bonhoeffer repeatedly makes confession the turning point of the discussion regardless of the topic in hand or mode of expression and in so doing makes confession indispensable to his theological position. 